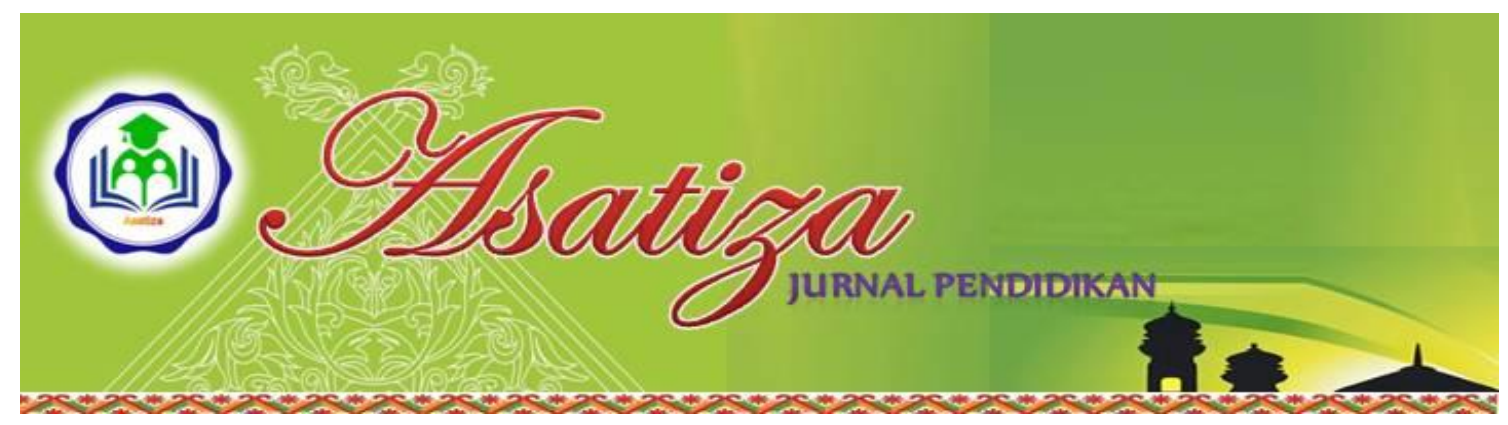

\title{
PERANAN GURU DALAM MENANGANI PELANGGARAN DISIPLIN SISWA DI MADRASAH TSANAWIYAH HIDAYATUL ISLAMIYAH KUALA LAHANG KECAMATAN GAUNG
}

\begin{abstract}
Nurvadila ${ }^{1}$
${ }^{1}$ STAI Auliaurrasyidin Tembilahan

Abstrak

Permasalahan dalam penelitian ini adalah bagaimana peranan guru dalam menangani pelanggaran disiplin siswa di Madrasah Tsanawiyah Hidayatul Islamiyah Kuala Lahang Kecamatan Gaung dan faktor-faktor yang mempengaruhi peranan guru dalam menangani pelanggaran disiplin siswa di Madrasah Tsanawiyah Hidayatul Islamiyah Kuala Lahang Kecamatan Gaung.

Subjek Dalam Penelitian Ini Adalah Guru. Sedangkan yang menjadi objek dalam penelitian ini adalah peranan guru dalam menangani pelanggaran disiplin siswa. Jenis penelitian yang digunakan adalah penelitian kuantitatif dengan teknik pengumpulan data menggunakan observasi yaitu 6 orang wali kelas, wawancara kepala sekolah, BK, waka kesiswaan, walikelas dan dokumentasi. Data dalam penelitian ini dianalisis dan dideskripsikan dengan pola pikir Induktif Deduktif. Selanjutnya data Kualitatif akan diubah ke dalam angka dengan menggnaakan rumus persentase.

Berdasarkan hasil penelitian dari Peranan guru dalam menangani pelanggaran disiplin siswa di Madrasah Tsanawiyah Hidayatul Islamiyah Kuala Lahang Kecamatan Gaung dengan persentase $61,1 \%$ dikategorikan "Baik" karena berada pada interval $61 \%-80 \%$.
\end{abstract}

Kata Kunci: Peranan Guru, Disiplin Siswa

\section{A. PENDAHULUAN}

\section{Latar belakang}

Sekolah merupakan lembaga pendidikan formal yang terdiri dari siswa-siswa yang memiliki latar belakang agama dan etnis yang berbeda-beda. sebagai institusi formal memiliki tugas dan fungsi penting yang tidak hanya meningkatkan kemampuan penguasaan dan informasi teknologi peserta didik, tetapi sekolah juga harus berperan dalam pembentukan karakter yang baik pada peserta didik.

Fungsi Pendidikan nasional menurut UU sisdiknas tahun 2003 pasal 3 adalah mengembangkan kemampuan dan membentuk watak serta peradaban bangsa yang bermartabat dalam rangka mencerdaskan kehidupan bangsa, bertujuan untuk berkembangnya potensi peserta didik agar menjadi manusia yang beriman dan bertakwa kepada Tuhan Yang Maha Esa, 
berakhlak mulia, sehat, berilmu, cakap, kreatif, mandiri, dan menjadi warga negara yang demokratis serta bertanggung jawab.

Kedudukan guru sebagai agen pembelajaran berkaitan dengan peran guru dalam pembelajaran, antara lain sebagai fasilitator, motivator, pemacu, perekayasa pembelajaran, dan pemberi inspirasi belajar bagi peserta didik. Peran tersebut menuntut guru untuk mampu meningkatkan kinerja dan profesionalismenya seiring dengan perubahan dan tuntutan yang muncul terhadap dunia pendidikan dewasa ini. ${ }^{1}$

Peranan (role) guru artinya keseluruhan tingkah laku yang harus dilakukan guru dalam melaksanakan tugasnya sebagai guru. Guru mempunyai peranan yang amat luas, baik di sekolah, keluarga, dan di dalam masyarakat. Guru berperanan di sekolah sebagai perancang atau perencana, pengelola pengajaran dan pengelola hasil pembelajaran siswa. Peranan guru di sekolah ditentukan oleh kedudukannya sebagai orang dewasa, sebagai pengajar dan pendidik serta sebagai pegawai. Berdasarkan kedudukannya sebagai guru, ia harus menunjukkan perilaku yang layak (bisa dijadikan teladan oleh siswanya). ${ }^{2}$ Dalam Mematuhi ke disiplinan yang ada di sekolah baik dalam jam pembelajaran maupun di luar jam pelajaran.

${ }^{1}$ Juni priansa, Manajemen kelas, Bandung: Alfabeta, 2015, hlm. 61.

2Tohirin, Psikologi pembelajaran pendidikan agama islam, Jakarta: PT Raja grafindo persada, 2011, hlm. 165.
Disiplin sekolah harus dimulai dilaksanakan dan dilakukan dari halhal kecil. Misalnya, datang kesekolah tepat waktu, siswa yang terlambat datang harus melapor kepada guru piket, pada saat jam pelajaran siswa tidak diperkenankan keluar masuk kelas, kecuali telah mendapat izin dari guru, aturan tentang sepatu, seragam yang rapi, menghormati kepala sekolah, semua guru, serta penjaga sekolah, rambut dan modelnya ${ }^{3}$.

Kepala sekolah memilih Guru Bimbingan Konseling (BK), Wakil kepala (waka) sekolah bidang Kesiswaan, dan setiap walikelas yang akan diberi tugas menangani pengembangan disiplin sekolah.

Menurut Tulus Tu'u dalam bukunya Peran disiplin pada perilaku dan prestasi siswa, mengatakan:

Guru-guru yang dipilih diharapkan dari guru-guru yang dikenal cukup disiplin dan tegas. Memiliki hati untuk terlibat dalam pengembangan disiplin. Dipilih beberapa orang, lalu dibentuk dalam tim disiplin. Ada satu orang jadi koordinator, boleh guru urusan kesiswaan, atau ditunjuk orang lain. Tim disiplin ini bertanggung jawab penuh kepada kepala sekolah. Tim disiplin inilah nantinya menjadi motor penggerak pengembangan dan kemajuan disiplin sekolah. $^{4}$

Adapun peraturan disiplin siswa di Madrasah Tsanawiyah Hidayatul

${ }^{3}$ Tulus Tu'u, Peran disiplin pada perilaku dan prestasi siswa, Jakarta: PT Grasindo, 2008, hlm. 116.

${ }^{4}$ Tulus Tu'u, ibid, hlm. 119. 
islamiyah kuala lahang kecamatan gaung sebagai berikut:

a. Setiap hari pelajaran dimulai pukul 07:15 WIB kecuali hari senin 07:00 WIB

b. Lima belas menit sebelum pelajaran dimulai, semua siswa harus sudah ada di sekolah.

c. Siswa yang terlambat datang harus melapor kepada sekolah atau guru piket atau guru kelas

d. Pada waktu pelajaran berlangsung siswa tidak diperkenankan keluar masuk ruangan kelas, kecuali telah mendapat izin dari guru kelas

e. Siswa yang berhalangan mengikuti pelajaran, apapun alasannya, orang tua atau walinya harus memberitahukan secara tertulis atau lisan kesekolah

f. Setiap hari siswa wajib berpakaian seragam sekolah sesuai dengan ketentuan, yaitu:

1) Hari senin selasa berpakaian seragam putih donker

2) Hari rabu kamis berpakaian pramuka

3) Hari jum'at berpakaian baju kurung muslim

4) Hari sabtu berpakaian olahraga

g. Siswa tidak boleh memakai perhiasan yang berlebihan di sekolah untuk menghindari hal-hal yang tidak diinginkan

h. Siswa harus berpakaian sopan dan rapi, baik di sekolah maupun di luar sekolah i. Setiap siswa wajib bersikap hormat kepada kepala sekolah, semua guru, serta penjaga sekolah lainnya.

j. Setiap siswa wajib mengikuti salah satu kegiatan sekolah, seperti upacara bendera, senam kesegaran jasmani, kepramukaan, praktik olahraga. $^{5}$

Namun disekolah masih ada guru yang kurang memperhatikan kedisiplinan disekolah. Dalam kata lain terdapat kesenjangan antara teori kedisiplinan dengan yang terjadi di lapangan. Hal tersebut terbukti dari gejala-gejala yang peneliti temukan diantaranya:

a. Masih ada siswa terlamabat hadir kesekolah pada waktu yang telah ditentukan

b. Masih ada siswa yang meninggalkan kelas tanpa meminta Izin kepada guru yang sedang mengajar

c. Masih ada siswa yang tidak memakai sepatu hitam di waktu jam sekolah

d. Masih ada siswa yang tidak berpakaian rapi di waktu jam sekolah

Guru yang terlibat dalam menangani pelanggaran disiplin siswa di Sekolah Madrasah Tsanawiyah Hidayatul Islamiyah Kuala Lahang Kecamatan Gaung diantara nya: Wali kelas, Waka Kesiswaan, Bimbingan Konseling (BK), dan Kepala Sekolah.
${ }^{5}$ Peraturan Disiplin Siswa Di Madrasah Tsanawiyah Hidayatul Islamiyah Kuala Lahang Kecamatan Gaung 


\section{Pengertian Peranan Guru}

Pengertian guru dalam konteks pendidikan terkait dengan profesi yang diembannya sebagai pendidik dan pengajar bagi peserta didik yang ada di berbagai jenjang pendidikan. Secara umum, baik dalam pekerjaan ataupun sebagai profesi, guru selalu disebut sebagai salah satu komponen utama pendidikan yang sangat penting. Melalui guru, peserta didik dapat memperoleh transfer pengetahuan dan pemahaman yang dibutuhkan untuk pengembangan dirinya.

Dalam undang-undang nomor 14 tahun 2005 tentang guru dan dosen, pasal 1 ayat 1 ditegaskan pula bahwa:

Guru adalah pendidik profesional dengan tugas utama mendidik, mengajar, membimbing, mengarahkan, melatih, menilai, dan mengevaluasi peserta didik pada pendidikan anak usia dini jalur pendidikan formal, pendidikan dasar, dan pendidikan menengah. ${ }^{6}$

Seiring dengan ketentuan tersebut, peraturan pemerintah Nomor 74 Tahun 2008 tentang guru, pasal 52 ayat (1) menegaskan pula tentang tugas pokok guru: Tugas pokok guru, yaitu: Merncanakan pembelajaran, melaksanakan pembelajaran, menilai hasil pembelajaran, membimbing dan melatih pserta didik, dan melaksanakan tugas tambahan yang melekat pada pelaksanaan kegiatan pokok sesuai dengan beban kerja guru. $^{7}$

Secara normatif, guru adalah mereka yang bekerja di sekolah atau madrasah, mengajar, membimbing, melatih para siswa agar mereka memiliki kemampuan dan keterampilan untuk melanjutkan kejenjeng pendidikan yang lebih tinggi, juga dapat menjalani kehidupan dengan baik. ${ }^{8}$

Peranan (role) guru artinya keseluruhan tingkah laku yang harus dilakukan dalam melaksanakan tugasnya sebagai guru. Guru mempunyai peranan yang amat luas, baik disekolah, keluarga, dan didalam masyarakat. Disekolah guru berperan sebagai perancang atau perencana, pengelola pengajaran dan pengelola hasil pembelajaran siswa. Peranan guru disekolah ditentukan oleh kedudukannya sebagai orang dewasa, sebagai pengajar dan pendidik serta sebagai pegawai. Yang paling utama adalah kedudukannya sebagai pengajar dan pendidik, yakni sebagai guru. Berdasarkan kedudukannya sebagai guru, ia harus menunjukkan prilaku yang layak (bisa dijadikan teladan oleh siswanya). ${ }^{9}$

Mengenai apa peranan guru itu ada beberapa pendapat yang dijelaskan sebagai berikut:
${ }^{6}$ Undang-Undang Republik Indonesia Nomor 14 Tahun 2005 Tentang Guru Dan Dosen.

${ }^{7}$ Donni juni priansa, Kinerja dan profesionalisme guru, Bandung: Alfabeta, 2014, hlm. 37.

${ }^{8}$ Chaerul Rochman,dkk, Pengembangan kompetensi kepribadian guru menjadi pendidik yang dicintai dan diteladani siswa, Bandung: Nuansa, 2016, hlm. 25.

${ }^{9}$ Tohirin, Psikologi pembelajaran pendidikan agama islam, Jakarta: PT Rajagrafindo persada, 2011, hlm. 165. 
a. Prey Katz, menggambarkan peranan guru sebagai komunikator, sahabat yang dapat memberikan nasihat-nasihat, motivator sebagai pemberi inspirasi dan dorongan, pembimbing dalam pengembangan sikap dan tingkah laku serta nilainilai, orang yang menguasai bahan yang diajarkan.

b. Havighurst, menjelaskan bahwa peranan guru di sekolah sebagai pegawai (employee) dalam hubungan kedinasan, sebagai bawahan, (subordinate) terhadap atasannya, sebagai kolega dalam hubungannya dengan teman sejawat, sebagai mediator dalam hubungannya dengan anak didik, sebagai pengatur disiplin, evaluator dan pengganti orang tua.

c. James W. Brown, mengemukakan bahwa tugas dan peranan guru antara lain: menguasai dan mengembangkan materi pelajaran, merencana dan mempersiapkan pelajaran sehari-hari, mengontrol dan mengevaluasi kegiatan siswa.

\section{d. Federasi dan Organisasi} Profesional Guru Sedunia, mengungkapkan bahwa peranan guru di sekolah, tidak hanya sebagai transmiter dari ide tetapi juga berperan sebagai transfomer dan katalisator dari nilai dan sikap. $^{10}$

\section{Pengertian Disiplin}

Istilah disiplin berasal dari bahasa latin "Disciplina" yang menunjuk kepada kegiatan belajar dan mengajar. Dalam bahasa Indonesia istilah disiplin kerapkali terkait dan menyatu dengan istilah tata tertib dan ketertiban. Istilah ketertiban mempunyai arti kepatuhan seseorang dalam mengikuti peraturan atau tata tertib karena didorong atau disebabkan oleh sesuatu yang datang dari luar dirinya. Sebaliknya, istilah disiplin sebagai kepatuhan dan ketaatan yang muncul karena adanya kesadaran dan dorongan dari dalam diri orang itu istilah tata tertib berarti perangkat peraturan yang berlaku untuk menciptakan kondisi yang tertib dan teratur. ${ }^{11}$

Disiplin berarti suatu sikap menghormati, menghargai, patuh dan taat terhadap peraturan- peraturan yang berlaku, baik yang tertulis maupun tidak tertulis serta sanggup mengjalankannnya dan tidak mengelak untuk menerima sanksisanksinya apabila ia melanggar tugas dan wewenang yang diberikan kepadanya. $^{12} \quad$ Kedisiplinan menyangkut giatnya usaha dan memenuhi targer serta waktu yang tepat. Berarti disiplin dalam bekerja dan disiplin waktu. ${ }^{13}$

a. Fungsi Disiplin.

Disiplin sangat penting dan dibutuhkan oleh setiap siswa.

Disiplin menjadi prasyarat bagi

\footnotetext{
${ }^{12}$ Eman suherman, Op.Cit, hlm. 52.

${ }^{13}$ Sofyan S.Willis, Psikologi pendidikan, Bandung: Alfabeta, 2012, hlm. 155.
}

mengajar,Jakarta: PT Raja grafindo persada,2016. hlm. 143-144.

${ }^{11}$ Tulus Tu'u, Op.Cit, hlm. 30-31. 
pembentukan sikap, prilaku dan tata kehidupan berdisiplin, yang akan mengantar seorang siswa sukses dalam belajar dan kelak ketika bekerja. ${ }^{14}$

b. Pembentukan disiplin

Dalam rumusan dan sistematika bagian tentang disiplin, ada empat hal yang dapat mempengaruhi dan membentuk disiplin. Keempat faktor ini merupakan faktor dominan yang mempengaruhi dan membentuk disiplin. Alasannya sebagai berikut:

1) Kesadarn diri sebagai pemahaman diri bahwa disiplin dianggap penting bagi kebaikan dan keberhasilan dirinya.

2) Pengikut dan ketaatan sebagai langkah penerapan dan praktik peraturan-peraturan yang mengatur prilaku individunya. Hal ini sebagai kelanjutan dari adanya kesadaran diri yang dihasilkan oleh kemampuan dan kemauan diri yang kuat. Tekanan dari luar dirinya sebagai upaya mendorong, menekan dan memaksa agar disiplin diterapkan dalam diri seseorang sehingga praturanpraturan diikuti dan diperaktikkan.

3) Alat pendidik untuk mempengaruhi, mengubah, membina dan membentuk prilaku yang sesuai dengan nilai-nilai yang ditentukan atau diajarkan.

${ }^{14}$ Tulus Tu'u, Op.Cit, hlm.38.

15 Tulus Tu'u Ibid, hlm. 48-49.
4) Hukuman sebagai upaya menyadarkan, mengoreksi dan meluruskan yang salah sehingga orang kembali pada prilaku yang sesuai dengan harapan. ${ }^{15}$

c. Pelanggaran Disiplin.

Bentuk-bentuk pelanggaran disiplin siswa yang kerap kali terjadi antara lain: bolos, tidak mengerjakan tugas dari guru, mengganggu kelas yang sedang belajar, menyontek, tidak memperhatikan pelajaran yang sedang dijelaskan oleh guru, berbicara dengan teman sebelahnya saat pelajaran berlangsung, terlambat hadir kesekolah. ${ }^{16}$

d. Penanggulangan disiplin.

Disiplin individu menjadi prasyarat terbentuknya kepribadian yang unggul dan sukses. Disiplin sekolah menjadi prasyarat terbentuknya lingkungan pendidikan yang kondusif bagi kegiatan dan proses pendidikan. Oleh karena itu, kepala sekolah, guru-guru dan orang tua perlu terlibat dan bertanggung jawab membangun disiplin siswa dan disiplin sekolah.

Dengan keterlibatan dan tanggung jawab itu, diharapkan para siswa berhasil dibina dan sukses. Keunggulan dan kesuksesan itu terwujud sebab sekolah berhasil menciptakan lingkungan yang kondusif bagi kegiatan dan proses pendidikan. Siswa terpacu untuk

\footnotetext{
${ }^{16}$ Tulus Tu'u, Ibid, hlm.55.
} 
mengoptimalkan potensi dan prestasi dirinya.

Dalam penanggulangan disiplin, beberapa hal berikut ini perlu mendapat perhatian:

a. Adanyaa tata tertib. Dalam mendisiplinkan siswa, tata tertib sangat bermanfaat untuk membiasakannya dengan standar prilaku yang sama dan diterima oleh individu lain dalam ruang lingkupnya. Dengan standar yang sama ini, diharapkan tidak ada diskriminasi dan rasa ketidak adilan pada individu-individu yang ada di lingkungan tersebut. Disamping itu, adanya tata tertib, para siswa tidak dapat lagi bertindak dan berbuat sesuka hatinya.

b. Konsisten dan konsekuen. Masalah umum yang muncul dalam disiplin adalah tidak konsistennya penerapan disiplin. Ada perbedaan antara tata tertib yang tertulis dengan pelaksanaan di lapangan. Dalam sanksi atau hukuman ada perbedaan antara pelanggar yang satu dengan yang lain. Sugeng Prijodarmintodalam Tulus Tu'u, dalam bukunya peran disiplin pada prilaku dan prestasi siswa, mengatakan: Dalam menegakkan disiplin bukanlah ancaman atau kekerasan yang di utamakan. Yang diperlukan adalah ketegasan dan keteguhan di dalam melaksanakan pereturan. Hal itu merupakan modal utama dan syarat mutlak untuk mewujudkan disiplin. c. Hukuman. Hukuman bertujuan mencegah tindakan yang tidak baik atau tidak diinginkan.

d. Kemitraan dengan orang tua. Pembentukan individu berdisiplin dan penanggulangan masalahmasalah disiplin tidak hanya menjadi tanggung jawab sekolah, tetapi juga tanggung jawab orang tua atau keluarga. Keluarga atau orang tua merupakan pendidik pertama dan utama yang sangat besar pengaruhnya dalam pembinaan dan pengembangan prilaku siswa. Karena itu, sekolah sangat perlu bekerja sama dengan orang tua dalam penanggulangan masalah disiplin. ${ }^{17}$

e. Strategi Disiplin Sekolah

1) Prioritas. Disiplin sekolah seharusnya menjadi prioritas dalam program sekolah yang disusun oleh kepala sekolah bersama-sama guru. Ada tujuan yang ingin dicapai dengan pengembangan disiplin sekolah. Misalnya, tujuan program disiplin sekolah: Disiplin sekolah meningkat atau sekolah menjadi sekolah berdisiplin tinggi, atau disiplin menjadi bagian karakter siswa, atau siswa menjadi biasa dalam disiplin. Dalam hal ini, kepala sekolah merupakan orang yang paling bertanggung jawab dalam pengembangan disiplin sekolah. Kepala sekolah merupakan orang kunci (key person). Kepala sekolah motor utama

${ }^{17}$ Tulus Tu’u, Ibid, hlm. 55-57. 
penggerak berjalannya disiplin sekolah. Dia lah yang menempatkan disiplin sekolah menjadi prioritas programnya.

2) Mulai hal kecil. Disiplin yang dikembangkan tidak dapat terwujud sekaligus dalam waktu yang singkat. Disiplin terbentuk tidak seperti membalikkan tangan. Perlu perjuangan dan usaha keras guru-guru bersama kepala sekolah. Disiplin sekolah harus dimulai dilaksanakan dan dilakukan dari hal-hal kecil. Misalnya, aturan tentang sepatu, seragam yang rapi, kehadiran disekolah, barang-barang yang dibawa, rambut dan modelnya.

3) Minta dukungan Dalam pengembangan dan pelaksanaan disiplin sekolah, perlu mendapat dukungan kuat dari berbagai pihak. Pihak-pihak yang perlu diminta dukungannya adalah guru-guru, orang tua dan para siswa sendiri. Permintaan dukungan guru-guru disampaikan dalam rapat guru. Permintaan dukungan orang tua disampaikan dalam acara pertemuan dengan orang tua, yang diundang khusus awal tahun ajaran untuk menjelaskan program sekolah. Permintaan dukungan siswa disampaikan dalam upacara bendera.

4) Persetujuan. Peraturan sekolah yang telah disusun oleh pihak sekolah disampaikan kepada siswa dan orang tua. Mereka diminta untuk mempelajarinya dengan baik. Sesudah itu, siswa menandatangani pernyataan telah membaca, memahami, menyetujui dan bersedia melaksanakan. Apabila kelak melanggar ketentuan yang berlaku, bersedia untuk menerima sanksi disiplin yang diberikan oleh sekolah.

5) Konsisten dan konsekuan. Tata tertib yang sudah di sampaikan kepada siswa dan orang tua beserta guru-guru di sekolah harus dilaksanakan dengan baik. Artinya, semua pihak didorong untuk melaksanakan sesuai dengan yang tertulis dalam lembaran tata tertib sekolah. Apabila ada yang sampai melanggar tata tertib tersebut, yang bersangkutan harus bertanggung jawab. Tanggung jawab itu berupa kerelaan menerima saksi disiplin yang diberikan oleh sekolah. Saksi itu perlu sesuai dengan ketentuan yang berlaku. Tidak ada perlakuan yang berbeda. Semua berdasarkan standar yang sama.

6) Perjanjian. Tata tertib sekolah dibuat dan disusun dengan tujuan menolong siswa menjadi lebih mandiri dan bertanggung jawab. Disiplin sekolah menjadi alat pendidikan bagi pengembangan kepribadian yang lebih dewasa. Bila ada siswa yang melanggar, mereka diberi sanksi yang mendidik. Bila ada yang melanggar berulangkali, diberi sanksi lebih berat. Bila ada yang agak berat bobot pelanggarannya, perlu 
dilakukan dengan perjanjian di atas material. Bila melanggar lagi, harus mengundurkan diri atau diminta keluar dari sekolah.

7) Tim disiplin. Untuk merancang, melaksanakan, mengawasi dan mengevaluasi kegiatan disiplin sekolah, kepala sekolah perlu membentuk tim disiplin sekolah. Tim disiplin ini diberi tugas dan wewenang oleh kepala sekolah untuk melaksanakan seluruh pengembangan kegiatan disiplin sekolah dan bertanggung jawab kepada kepala sekolah. Hal-hal yang kecil dapat langsung diselesaikan. Hal-hak yang besar menyangkut pemberhentian dan pemberian saksi disiplin berat harus dibicarakan bersama kepala sekolah. Agar kepala sekolah tahu persis persoalan yang terjadi termasuk kebijakanyang diambil sekolah.

8) Guru BP dan Wali kelas. Tim disiplin yang memberi saksi disiplin dapat juga berfungsi membina dan membimbing siswa. Guru BP dan wali kelas perlu juga dilibatkan dan ambil bagian dalam pembinaan siswa bermasalah tersebut.

9) Moto sekolah. Sekolah dapat membuat moto sekolah berkenaan dengan kebijakan sekolah. Sekolah juga dapat membuat moto sekolah berkenaan dengan pengembangan disiplin sekolah.
Misalnya, disiplin kunci sukses, dan disiplin bagian iman, tiada sukses tanpa disiplin, dan disiplin karakter unggul. ${ }^{18}$

f. Bimbingan Dan Pembinaan Disiplin

Bimbingan belajar merupakan bagian integral dari pelaksanaan pendidikan di sekolah. Untuk pembinaan disiplin, perlu dibuat tata tertib sekolah, yaitu ketentuanketentuan yang mengatur kehidupan sekolah sehari-hari dan mengandung sangsi terhadap pelanggarnya. Aturan-aturan tersebut berupa aturan cara berpakaian, sikap siswa terhadap kepala sekolah, sikap siswa terhadap guru, sikap siswa terhadap sesama siswa, sikap siswa terhadap karyawan, dan aturan-aturan lain yang berkaitan dengan kesiswaan. ${ }^{19}$

Adapun Tata tertib menurut Tulus Tu'u dalam bukunya peran disiplin pada prilaku dan prestasi siswa, yaitu $^{20}$ :

1) Kehadiran di Sekolah Siswa wajib hadir di kelas sebelum pelajaran dimulai

2) Meninggalkan Kelas Dan Sekolah.

a) Pada saat pelajaran berlangsung, siswa yang akan meninggalkan kelas harus meminta izin kepada guru yang sedang mengajar.
${ }^{18}$ Tulus Tu'u, ibid, hlm. 115-116.

${ }^{19} \mathrm{M}$ Sobry Sutikno, Manajemen pendidikan langkah praktis mewujudkan lembaga pendidikan yang unggul (Tinjauan Umum Dan Islam), Lombok: holistica, 2012, hlm. 78.

${ }^{20}$ Tulus Tu'u Op.cit, hlm. 132-135. 
b) Pada waktu pergantian jam pelajaran, siswa tidak diperkenankan keluar dari kelas sebelum mendapat izin dari guru yang akan mengajar pada jam berikutnya

c) Siswa yang meninggalkan sekolah karena sakit/ ditugaskan oleh sekolah harus meminta izin terlebih dahulu kepada guru piket

d) Selama jam pelajaran berlangsung siswa dilarang keluar lingkungan sekolah tanpa izin dari guru piket

3) Keterlambatan Dan Ketidak hadiran

4) Pakaian Seragam

a) Siswa wajib berpakaian seragam sekolah secara rapi

b) Sepatu yang dipakai harus hitam, tertutup dan jika bertali harus memakai tali sepatu hitam dan berkaos kaki putih polos

c) Pakaian seragam dan sepatu olahraga hanya dipakai pada saat jam olahraga.

5) Sikap Dan Tutur Kata Dalam Pergaulan

a) Siswa wajib menghormati guru-guru, penata usaha dan tamu

b) Siswa tidak boleh mengucapkan kata-kata kasar dan kotor.

6) Rambut Dan Perhiasan

a) Potongan rambut model seorang pelajar, rapi, dan tidak diwarnai b) Tidak memakai perhiasan yang berlebihan dan gelan kaki.

7) Makanan, Minuman, Kebersihan Dan Kelengkapan Sekolah

a) Siswa dilarang jajan, makan/ minum di kelas selama jam pelajaran berlangsung

b) Siswa dilarang membuang sampah di sembarang tempat

c) Siswa wajib menjaga perlengkapan kelas.

\section{METODOLOGI}

Berdasarkan pada batasan masalah, jenis penelitian ini adalah deskriptif kuantitatif. yang menjadi subjek penelitian yaitu Guru di Sekolah Madrasah Tsanawiyah Hidayatul Islamiyah Kuala Lahang Kecamatan Gaung. Objek dalam penelitian ini yaitu Peranan Guru Dalam Menangani Pelanggaran Disiplin Siswa di Madrasah Tsanawiyah Hidayatul Islamiyah Kuala Lahang Kecamatan Gaung Dalam penelitian ini, yang menjadi populasi adalah Guru Wali kelas 6 orang, Waka Kesiswaan, dan Bimbingan Konseling (BK) 1 Orang, serta Kepala Sekolah di Madrasah Tsanawiyah Hidayatul Islamiyah Kuala Lahang Kecamatan Gaung. Teknik Pengumpulan Data: Observasi, wawancara dan dokumentasi. Data dalam penelitian ini dianalisis dan dideskripsikan dengan pola pikir Induktif Deduktif. Selanjutnya data Kualitatif akan diubah ke dalam angka 
dengan cara mempersentasekannya sesuai dengan frekuensi yang didapat.

\begin{tabular}{|c|c|c|c|c|c|}
\hline \multirow{2}{*}{ NO } & \multirow{2}{*}{ TABEL } & \multicolumn{3}{|c|}{ REKAPITULASI } \\
\cline { 3 - 6 } & & \multicolumn{3}{|c|}{ JAWABAN } \\
\cline { 3 - 6 } & & F & \% & F & \% \\
\hline 1 & Pertemuaan 1 & 4 & 40 & 6 & 60 \\
\hline 2 & Pertemuaan 2 & 6 & 60 & 4 & 40 \\
\hline 3 & Pertemuaan 3 & 7 & 70 & 3 & 30 \\
\hline 4 & Pertemuaan 4 & 6 & 60 & 4 & 40 \\
\hline 5 & Pertemuaan 5 & 7 & 70 & 3 & 30 \\
\hline 6 & Pertemuaan 6 & 8 & 80 & 2 & 20 \\
\hline 7 & Pertemuaan 7 & 4 & 40 & 6 & 60 \\
\hline 8 & Pertemuaan 8 & 6 & 60 & 4 & 40 \\
\hline 9 & Pertemuaan 9 & 7 & 70 & 3 & 30 \\
\hline 10 & Pertemuaan 10 & 5 & 50 & 5 & 50 \\
\hline 11 & Pertemuaan 11 & 6 & 60 & 4 & 40 \\
\hline 12 & Pertemuaan 12 & 8 & 80 & 2 & 20 \\
\hline 13 & Pertemuaan 13 & 5 & 50 & 5 & 50 \\
\hline 14 & Pertemuaan 14 & 6 & 60 & 4 & 40 \\
\hline 15 & Pertemuaan 15 & 8 & 80 & 2 & 20 \\
\hline 16 & Pertemuaan 16 & 4 & 40 & 6 & 60 \\
\hline 17 & Pertemuaan 17 & 5 & 50 & 5 & 50 \\
\hline 18 & Pertemuaan 18 & 8 & 80 & 2 & 20 \\
\hline & JUMLAH & $\mathbf{1 1 0}$ & $\mathbf{6 2}$ & $\mathbf{7 0}$ & $\mathbf{3 8}$ \\
\hline
\end{tabular}

Pernyataan observasi:

1. Guru mengarahkan kepada siswa agar datang kesekolah, 15 menit sebelum jam pelajarn dimulai

2. Guru memanggil siswa yang terlambat datang ke sekolah harus melapor kepada guru piket

3. Guru memerintahkan kepada siswa untuk selalu menghormati kepala sekolah

4. Guru memerintahkan kepada siswa untuk selalu menghormati guru-guru

5. Guru memerintahkan kepada siswa berpakaian seragam sekolah sesuai dengan ketentuan yang telah ditetapkan

6. Guru melarang siswa menggunakan sepatu berwarna, kecuali berwarna hitam
7. Guru melarang siswa berbicara dengan temannya saat pelajaran berlangsung

8. Guru melarang siswa menyontek tugas temannya saat guru memberikan tugas latihan kepada siswa

9. Guru memerintahkan kepada siswa untuk memperhatikan pelajaran yang sedang berlangsung

10. Guru melarang siswa bolos sebelum jam pelajaran selesai

Dari rekapitulasi data di atas, maka dapat diketahui bahwa hasil observasi untuk alternatif jawaban "ya" berjumlah 110, sedangkan untuk alternatif jawaban "tidak" berjumlah 70. Untuk memperoleh hasil observasi tentang Peranan Guru Dalam Menangani Pelanggaran Disiplin Siswa Di Madrasah Tsanawiyah Hidayatul Islamiyah Kuala Lahang Kecamatan Gaung diperoleh melalui rumus sebagai berikut:

$$
\mathrm{P}=\frac{\mathrm{F}}{\mathrm{N}} x 100 \%
$$

Untuk mendapatkan nilai $\mathrm{F}$ dengan cara memberikan bobot Ya (1) dan tidak $(0)^{21}$

1. Untuk alternatif jawaban "Ya" dengan bobot 1 sehingga didapatkan hasil: $110 \times 1=110$

2. Untuk alternatif jawaban "Tidak" dengan bobot 0 sehingga didapat nilai: $70 \times 0=0$

Untuk kedua hasil tersebut dijumlahkan menjadi nilai $\mathrm{F}=110+0=110$ Sehingga $F=110$

${ }^{21}$ Ridwan. Op, Cit hlm.91 
Untuk memperoleh nilai $\mathrm{N}$ dengan menggunakan rumus sebagai berikut:

$\mathrm{N}=$ Item $\mathrm{x}$ Skor tertinggi $\mathrm{x}$ jumlah observasi $\mathrm{x}$ responden

$$
\begin{aligned}
& \mathrm{N}=10 \times 1 \times 3 \times 6 \\
& \mathrm{~N}=180
\end{aligned}
$$

Setelah itu untuk mencari rata-rata persentase dengan mengunakan rumus sebagai berikut:

$$
\begin{aligned}
& P=\frac{F}{N} \times 100 \% \\
& P=\frac{110}{180} \times 100 \% \\
& P=\mathbf{6 1 , 1 \%}
\end{aligned}
$$

Lalu alat ukur Peranan Guru Dalam Menangani Pelanggaran Disiplin Siswa Di Madrasah Tsanawiyah Hidayatul Islamiyah Kuala Lahang Kecamatan Gaung adalah:

1. Angka $81 \%-100 \%=$ Sangat Baik

2. Angka $61 \%-80 \%=$ Baik

3. Angka $41 \%-60 \%=$ Cukup Baik

4. Angka $21 \%-40 \%=$ Tidak Baik

5. Angka 0\%-20\% = Sangat Tidak Baik $^{22}$

Dari hasil rata-rata rekapitulasi di atas dapat disimpulkan bahwa Peranan Guru Dalam Menangani Pelanggaran Disiplin Siswa Di Madrasah Tsanawiyah Hidayatul Islamiyah Kuala Lahang Kecamatan Gaung dengan persentase $61,1 \%$ dikategorikan "Baik" karena berada pada interval $61 \%-80 \%$.

Untuk mengetahui peranan guru dalam menangani pelanggaran disiplin siswa di madrasah tsanawiyah hidayatul islamiyah kuala lahang Kecamatan gaung, maka dalam pembahasan ini penulis akan menganalisa data yang telah dijelaskan di atas dalam bentuk deskriptif.

Pada bagian ini, penulis akan mendeskripsikan lebih dalam mengenai hasil dari pengamatan dan wawancara yang telah didapat. Penulis akan mendeskripsikan keterkaitannya dengan identifikasi-identifikasi masalah penelitian.

Setelah data penelitian disajikan dan dibahas sesuai dengan teknik pengumpulan data yang dilakukan, yaitu dengan melakukan wawancara kepada walikelas, kepala sekolah, waka kesiswaan dan bimbingan konseling (BK) di madrasah tsanawiyah hidayatul islamiyah kuala lahang Kecamatan gaung, Maka pada tahap selanjutnya penulis melakukan analisa data yang sudah diperoleh, berdasarkan hasil wawancara yang telah penulis lakukan kepada walikelas, kepala sekolah, waka kesiswaan dan bimbingan konseling (BK) di Madrasah Tsanawiyah Hidayatul Islamiyah Kuala Lahang Kecamatan Gaung.

Adapun hasil yang penulis peroleh dari kegiatan wawancara yang dilakukan dapat kami rangkum sebagai berikut:

a. Guru telah mengupayakan peranannya dalam menangani pelanggaran disiplin siswa

b. Guru telah memiliki sikap antusias dalam menangani pelanggaran disiplin siswa

${ }^{22}$ Ridwan, Op, Cit, hlm 89 
c. Adanya peranan serius guru dalam menangani pelanggaran disiplin siswa

d. Guru telah melakukuan penerapan kedisiplinan yang baik terhadap siswa

e. Faktor lingkungan Pergaulan sangat berpengruh terhadap siswa sebagai salah satu penentu berhasilnya disiplin siswa

f. Guru telah melakukan bimbingan yang baik, dan memberikan hukuman sesuai dengan pelanggaran yang dilakukan siswa.

Berdasarkan data hasil observasi dapat dianalisa bahwa peranan guru dalam menangani pelanggaran disiplin siswa di Madrasah Tsanawiyah Hidayatul Islamiyah Kuala Lahang kecamatan Gaung mencapai angka $61,1 \%$ dan dikategorikan baik, karena angka $61,1 \%$ terletak pada interval 61\%-80\%. Baik

Dari sejumlah wawancara yang telah dilakukan penulis, dapat dilakukan pembahasan sebagai berikut:

Dalam peranan Guru Dalam Menangani Pelanggaran Disiplin Siswa di Madrasah Tsanawiyah Hidayatul Islamiyah Kuala Lahang Kecamatan Gaung guru telah melaksanakan tugas nya sebagai guru untuk membina, mendidik, membimbing, menasehati, dan mengatur kedisiplinan siswa.

Guru sudah berperan penting dalam Menangani Pelanggaran Disiplin Siswa di Madrasah Tsanawiyah Hidayatul Islamiyah Kuala Lahang Kecamatan Gaung, sesuai dengan peranannya sebagai seorang pendidik mengantur kedisiplinan siswa di sekolah dan mengatasi siswa yang bermasalah sesuai dengan pelanggaran siswa.

Secara umum guru di Madrasah Tsanawiyah Hidayatul Islamiyah Kuala Lahang Kecamatan Gaung, sudah menerapkan peranan nya dalam menangani pelanggaran disiplin siswa dengan baik, walaupun ada beberapa siswa yang kerapkali melanggar aturan dan tidak disiplin di sekolah.

\section{KESIMPULAN}

Dari hasil analisa data melalui observasi dan wawancara dapat disimpulkan sebagai berikut:

1. Peranan guru dalam menangani pelanggaran disiplin siswa di Madrasah Tsanawiyah Hidayatul Islamiyah Kuala Lahang Kecamatan Gaung dengan persentase $\quad 61,1 \%$ dikategorikan "Baik"

2. Faktor-faktor yang mempengaruhi baiknya peranan guru dalam menangani pelanggaran disiplin siswa di Madrasah Tsanawiyah Hidayatul Islamiyah Kuala Lahang Kecamatan Gaung adalah sebagai berikut: Guru mengharuskan siswa serius saat guru menjelaskan pelajaran, Guru membiasakan siswa menanamkan sikap disiplin pada diri siswa Guru selalu memberikan arahan kepada siswa agar tidak melakukan pelanggaran disiplin Guru melakukan pembinaan disiplin terutama pada diri sendiri dan melakukan pengelolaan disiplin secara konsisten dan tepat. 


\section{REFERENSI}

Burhan Burgin. 2010. Metodologi Penelitian Pendidikan, Jakarta: Prenata Media Group.

E. Mulyasa. 2016. Menjadi Guru Profesional Menciptakan Pembelajaran Kreatif Dan Menyenagkan, Bandung: $\mathrm{Pt}$ Remaja Rosdakarya.

https://Pgrikabnunukan.Files.Wordpress.C om/2012/09/Uu-No-20-Thn2003-Sisdiknas.Pdf Diakses Hari Rabu 11 Juli 2018: 9:45 Wib

https://Typoonline.Com/Kbbi/Menangani Diakses Hari Rabu 11 Juli 2018: 9:40 Wib

https://Typoonline.Com/Kbbi/Pelanggaran Diakses Hari Rabu 11 Juli 2018: 10:35 Wib

Mamang Etta Dkk. 2010. Metodologi Penelitian Pendekatan Praktis Dalam Penelitian, Yogyakarta: Andi Obset.

Musfiqon. 2012. Metodologi Penelitian Pendidikan, Jakarta: Prestasi Pustaka.

Nini Subini. 2012. Awas Jangan Jadi Guru Karbitan, Jogjakarta: Javalitera.

Priansa Donni Juni. 2014. Kinerja Dan Profesionalisme Guru, Bandung: Alfabeta.

Priansa Donni Juni. 2015. Manajemen Kelas Classroom Management, Bandung: Alfabeta.

Priansa Juni. 2015. Manajemen Kelas, Bandung: Alfabeta

Ridwan. 2008. Belajar Mudah Meneliti Untuk Guru-Karyawan Dan Peneliti Pemula, Bandung: Alfabeta.

Rochman Chaerul, Dkk. 2016. Pengembangan Kompetensi Kepribadian Guru Menjadi Pendidik Yang Dicintai Dan Diteladani Siswa, Bandung: Nuansa.
Sardiman. 2016. Interaksi \& Motivasi Belajar Mengajar, Jakarta: Pt Raja Grafindo Persada.

Soekanto Soerjono. 2007. Sosiologi Suatu Pengantar, Jakarta: Pt Raja Grafindo Persada.

Subagyo P. Joko. 2006. Metode Penelitian Dalam Teori Dan Praktek, Jakarta: Rineks Cipta.

Subana Dkk. 2005. Statistik Penelitian, Bandung: Pustaka Setia.

Sudijono Anas. 2008. Pengantar Statistika Pendidikan, Jakarta: Raja Grapindo Persada.

Sugiono. 2011. Metode Penelitian Pendidikan Pendekatan Kuantitatif Kualitatif Dan $R \& D$, Bandung: Alfabeta.

Suherman Eman. 2012. Manajemen Kelas, Bandung :S Alfabeta.

Sutikno M Sobry. 2012. Manajemen Pendidikan Langkah Praktis Mewujudkan Lembaga Pendidikan Yang Unggul (Tinjauan Umum Dan Islam), Lombok: Holistica.

Tohirin. 2011. Psikologi Pembelajaran Pendidikan Agama Islam, Jakarta: Pt Raja Grafindo Persada.

Tu'u Tulus. 2008. Peran Disiplin Pada Perilaku Dan Prestasi Siswa, Jakarta: Pt Grasindo.

Undang-Undang Republik Indonesia Nomor 14 Tahun 2005 Tentang Guru Dan Dosen.

Willis Sofyan S. 2012. Psikologi Pendidikan, Bandung: Alfabeta. 